IJMS 16 (2), 243-262 (2009)

\title{
RETURN TO EDUCATION IN MALAYSIA
}

\author{
RUSMAWATI SAID \\ Faculty Economics and Management \\ University Putra Malaysia \\ ASMADDY HARIS \\ Faculty of Economics and Muamalat \\ University Sains Islam Malaysia \\ ROBERT Mc.NABB \\ Cardiff Business School United Kingdom \\ Cardiff University, United Kingdom
}

\begin{abstract}
The aim of this paper is to present a picture of return to education in Malaysia over the period from 1984 to 1997 based on earning equations model. The paper employed a set of data comprising micro-level data from the Household Income Survey (HIS) for several years during the period 1984 to 1997. The main finding of this paper is the changes in the wage differentials favouring the middle level of education (secondary level of education) workers. In general, the results show that the return for each level of qualification declined between 1984 and 1997, especially at the higher levels (diploma and degree). Interestingly, the return to education for females at low levels of education is higher than the return by males. However, at higher levels of qualification, especially for those with secondary and high school qualifications, males traditionally have a higher return compared to females workers. The results also indicated a significant gender differential, however the differences has fallen over time.
\end{abstract}

Keywords: Labor demand; Wage differentials; Trade and labour market interaction; Technological change.

JEL classification codes: J21,J23,J31,O33.

\begin{abstract}
ABSTRAK
Artikel ini bertujuan memberi gambaran pulangan ke atas pendidikan di Malaysia sepanjang tahun 1984 hingga 1997 berasaskan model persamaan
\end{abstract}


pendapatan. Artikel ini telah menggunakan data peringkat mikro daripada kajian ini ialah perubahan di dalam perbezaan upah lebih cenderung kepada pekerja yang memiliki pendidikan di peringkat pertengahan (sekolah menengah). Secara umumnya, hasil kajian menunjukkan pulangan ke atas setiap tahap kelayakan akademik menurun di antara tahun 1984 dan 1997, khususnya di peringkat yang tinggi (diploma dan ijazah). Penemuan yang penting adalah pulangan ke atas pendidikan bagi wanita di peringkat pendidikan rendah adalah lebih tinggi berbanding pulangan yang diperoleh lelaki. Walau bagaimanapun, pada peringkat kelayakan yang tinggi khususnya bagi mereka yang memperoleh kelayakan peringkat menengah dan sekolah tinggi, pekerja lelaki secara tradisinya mempunyai pulangan yang tinggi berbanding pekerja wanita. Hasil kajian juga menunjukkan terdapat perbezaan jantina yang signifikan tetapi perbezaan ini mengalami penurunan sepanjang tempoh kajian.

\section{INTRODUCTION}

DTe importance of education and training to the analysis of wage -differential has been noted among the work of Chicago economists, and part of neoclassical labour. For example, Friedman in his doctoral work gathered that formal training has significant impact on the increment on the individual future earnings. In addition throughout the fifties, the impression on human capital quality was frequently documented in writings of several Chicago economists for instance Becker (1955) and Schultz (1959). Specifically the study by Miller (1955) identified Peducation as an important variable that can explain the differences between labour of income and type of occupation. Increasing access to free higher education and increasing the allocation of public education at all levels, tended to counterbalance those forces restricting access to -certain better paid occupations. Human capital factors are deemed to be a key determinant of return to education and wage differential. The analysis of return to education and wage differential are inter-related. Human capital factor can explain why individuals do not entirely capture the benefit of education and the return can be measured by wages. Acemoglu and Angrist (2000) analysed the impact of human capital on return to education and found evidence for substantial return to education. However, they also claimed that such returns, for example social return, are negligible. Based on this evidence, it is important to analyse the view of labour research on education and training due to the obvious link with human capital theory.

The analysis of return to education can be estimated using different types of measures, however, the foremost estimation equation was 
proposed by Mincer (1974) which relates the logarithm of wages with education, work experience, and different control variabls (Arrazola \& Heria, 2008). The discussion also can be conducted by different types of education, occupation, industry, country, age, and experience. Chung (2003) for example, estimated return to education for Malaysia focusing on the education at employees and employers. Using the 1997 Household Income Survey (HIS) he found a positive private return to education in Malaysia. Self and Grabowski (2004) examined the impact of education on income growth during the period 1966-1996. The results indicated that primary education has strong causal impact on economic growth in India. They also found that female education at all levels has potential for generating economic growth. The purpose of this paper is to present the trend of education in Malaysia and analyse returns to education in Malaysia during the period 1984 to 1997. It thus attempts to address a significant gap in the previous literature regarding the trend and importance of education. The rest of paper is organised as follows. Section II describes the data used, Section III discusses the trend of education in Malaysia, Section IV presents the empirical results, Section $\mathrm{V}$ provides the policy implication, and Section VI then concludes the discussion.

\section{Data and Methodology}

This study used HIS for the years 1984, 1989, 1982, 1995, and 1997, from which information on employment, wage, age, activity, location, status of employment, 3-digit occupation and 5-digit industry data were obtained. The Department of Statistics Malaysia (DOS) is responsible for the survey design, data collection, and the processing activities for the surveys. The survey covers both urban and rural areas of Malaysia. A two-stage stratified sample design was adopted for HIS. The first sampling stage was the definition of what we call Enumeration Blocks, which are geographical areas artificially created to have about 80-120 living quarters, each with a population of about 60 . In the second stage, living quarters were selected from each of the sampled Enumeration Blocks. The concept of a household is based on arrangements made by individuals residing within the same living quarters, individually or in groups, for food and other essentials. Thus, a household may consist of related and unrelated members.

We used HIS starting in year 1984 and ending in 1997 because we wanted to focus on changes in wages through the 1980s and 1990s which was 
during the restructural period from agricultural based to manufacturing based production. We did not cover the 1970s because variable definitions and measurement in the 1970s data are different from that of later years. In addition, we did not use the 2002 data, again because the definitions and measurement have been revised and cannot be compared with the previous data. We also did not use the 1999 HIS survey because the survey in 1999 was restricted and only involved 40,000 households.

\section{Methodology}

It is generally agreed that labour force participation and work profiles are influenced by education, occupation, and sector differences. Following Chung (2003), our concern here was to present the distribution of workers by different types of education. The model was estimated separately for each survey year and is of the form:

(1) $\ln W_{k i t}=\beta_{0}+\beta_{1} Q_{k i t}+\beta_{2} O c c_{k i t}+\beta_{3} A G E_{k i t}+$

$$
\beta_{4} A G E_{k i t}{ }^{2}+\beta_{5} M A L E_{k i t}+\beta_{6} M A R_{k i t}+\beta_{7} \operatorname{Ind}_{k i t}+\varepsilon_{k i t}
$$

where $W_{k i t}$ is the wage of individual $k$ working in sector $i$ at time $t$; $Q_{k i t}$ is a vector of dummy variables measuring the individual's level of education in sector $i$ at time $t ; O c c_{k i t}$ and is a vector of six occupation =dummies. $A G E_{k i t}$ and $A G E_{k i t}{ }^{2}$ refer to age and age squared respectively. SMALE $E_{k i t}$ is a dummy variable, indicating the gender of individual $k$ working at sector $i$ in period $t . M A R_{k i t}$ is a dummy variable if the worker is married, $I_{k i t}$ represents nine sector dummies, while $\varepsilon_{k i t}$ is the error term. The dependent variable is the logarithm of the monthly total labour -market income or earnings, and includes wages, bonuses, allowances, and overtime. For the qualification groups, we chosed no qualification as the reference group and no schooling was chosen as the control variable for education level. Occupation groups refer to professional, managerial, clerical, sales, service workers, and production workers. In this context, production workers is the occupational reference group, as we were interested in knowing the changes in wage differentials for occupational groups relative to production workers. Finally, the sector groups are mining and quarrying, manufacturing, electricity, gas and water, construction, the wholesale and retail trade, restaurants and hotels, transport, storage and communications, finance and business services and community and personal services. The manufacturing sector was chosen as a reference group since the study was interested 
in investigating the wage differentials for other sectors relative to the manufacturing sector.

\section{Trend of Education in Malaysia}

This section provides a brief story of education level in Malaysia based on the household income survey (HIS) data. For comparative purposes, Tables 1 and 2 provide information on levels of education and qualification by gender over the period from 1984 through to 1997. Education is measured in two ways, first using four education levels, which are "no schooling", "primary", "secondary", and "tertiary", and second by qualifications attained, which are divided into six categories of "No qualifications", "Other qualifications", "Lower Qualification of Education (LCE)", "Medium Qualification of Education (MCE)", "High School Qualification (HSCE)", "Diploma", and "Degree".

The level of qualification provides information that is more precise because it measures the specific qualifications of workers. Education level is more general because it measures groups of people who were at school for a certain period of time but who may not have achieved the equivalent qualification level. At the no qualification level, people with no qualifications are those with no schooling and with schooling including primary and secondary school, but who were not able to pass the LCE examination in Year 9. Other qualification levels are those people who had qualifications that cannot be translated or converted according to the Malaysian education system. Most of these people get their qualification from abroad. In Malaysia, primary education is from Years 1 to 6 and secondary school is from Years 7 to 11. In Year 11, there is another compulsory examination: the MCE. This qualification is important for those students to go into tertiary education, enabling students either to go on to advanced level Matriculation and the HSCE, or to take diploma courses and then degrees. The LCE is the basic qualification, and people with LCE are in secondary education, but those with secondary education do not necessarily have the LCE: they might have no qualifications or just the MCE. Based on this classification, people with "no schooling" and those with primary education have no qualifications at all. Secondary education levels, however, signify groups of people with no qualifications, LCE, and MCE qualifications. In the HIS survey, people are classed as having tertiary education if they hold HSCE, Diploma, or Degree qualifications. Nevertheless, tertiary education does not necessarily mean those people at the university level. 


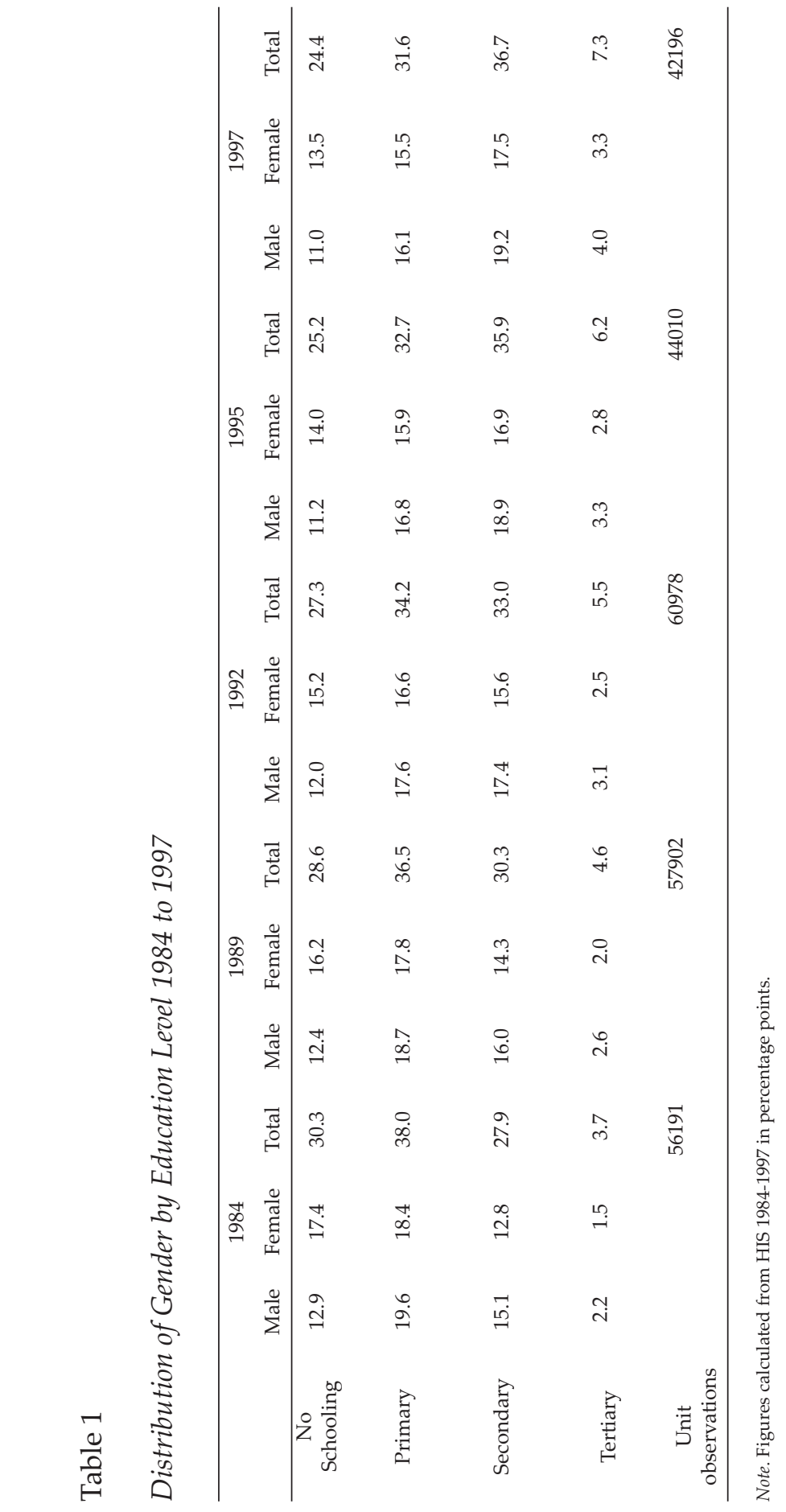

248 IJMS 16 (2), 243-262 (2009) 


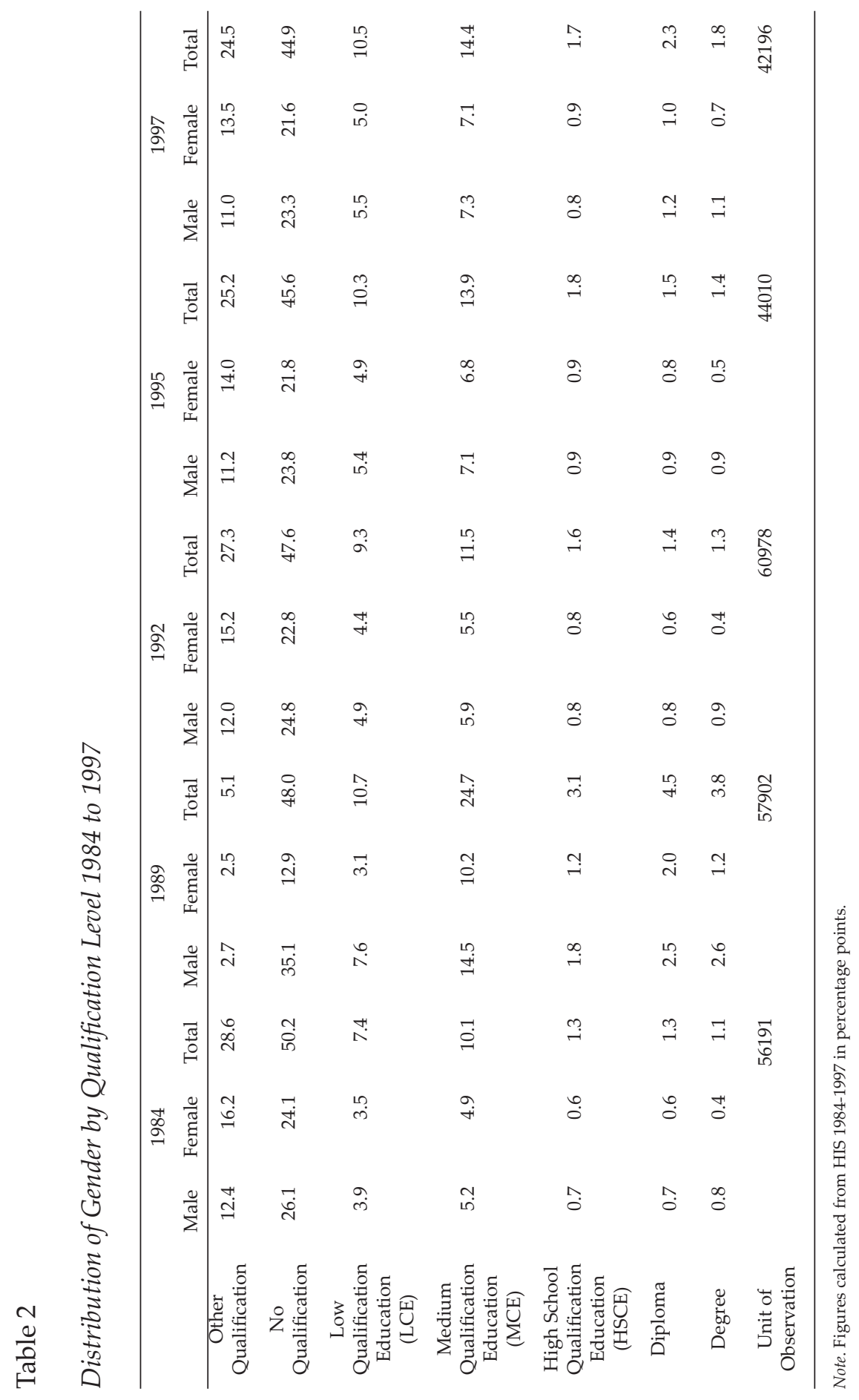

IJMS 16 (2), 243-262 (2009) 249 


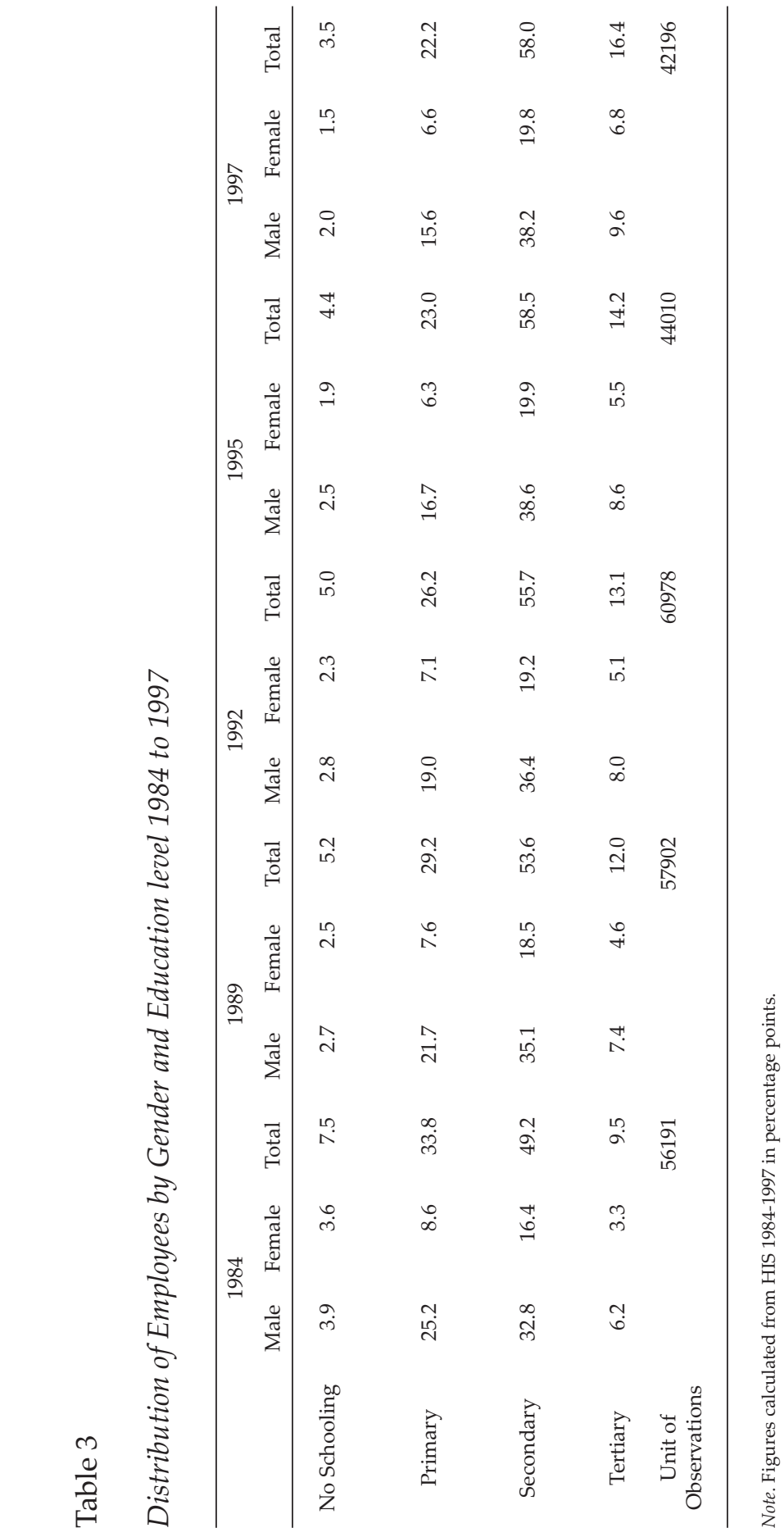

250 IJMS 16 (2), 243-262 (2009) 
If we look at types of education completed, Table 1 shows that in 1984, $68 \%$ of the population had only primary education or had no formal schooling. A further $27 \%$ had received secondary education and only $3.7 \%$ had achieved tertiary level education. Although these percentages showed a generally low level of education in Malaysia, the data also showed a marked improvement in the level of educational attainment over the period 1984-1997. The percentage of those with either primary education or no schooling has fallen to $56 \%$ in 1997, whereas the share of those with tertiary education had increased to $7 \%$. The number of people going to secondary schools increased by $10 \%$ in this period, from $27 \%$ in 1984 to $37 \%$ in 1997.

Table 2 shows the distribution of population in Malaysia by qualification level. Looking at 1984, 50.2 \% of the Malaysian population had no qualifications. This percentage, however, decreased to 44 \% by 1997. On average, $26 \%$ of the Malaysian population achieved no formal qualifications over the 1984-1997 period. Throughout the same period, the highest increment in qualification growth was for secondary qualifications. The growth in education level in this particular group was $4.3 \%$ during the sample period. People with primary qualifications saw a growth of $3.1 \%$, Diploma $1 \%$, High School $0.4 \%$ and Degree 0.7 $\%$.

Table 2 also shows the gender distribution of educational qualifications. There are a number of interesting gender differences in the education distributions. Firstly, women are more likely to have received no formal schooling, although the incidence of this had fallen dramatically by 1997. In contrast, the proportion of women achieving tertiary level education was significantly less than that of men in 1984, but the gap had narrowed in 1997. The differences noted above in terms of level of schooling did not seem to be reflected in the distribution of qualifications. This probably reflects the fact that around half of the population did not have any qualifications. Not unexpectedly, the proportion of women with higher-level qualifications was about half that of men in 1997, although the figures for both males and females were small. This does, however, represent a significant improvement since 1984.

\section{Distribution of Employees by Education}

As this paper is concerned with employees, this section discusses how education is distributed across employees, the distribution is 
as presented in Table 3. Generally, workers are most likely to have secondary education, with $58 \%$ of workers in 1997 having secondary education. The size of this particular group of workers had increased by almost $8.8 \%$ over the sample period. Although the number of workers with tertiary education was below $20 \%$, the number of workers with tertiary education had almost doubled from 1984. The contribution of workers with primary education to the labour force was relatively high, at around $33 \%$ in 1984. However, the percentage in this particular group decreased continuously throughout the sample period. A decreasing trend of workers also occurred in the 'no schooling' category. The number of workers with no schooling in 1997 was almost half that of workers in the same category in 1984. Comparing the results from Tables -1 and 3 yield the conclusion that non-production workers are likely to have primary education or no schooling.

Table 3 also shows the distribution of employees by gender and education. Table 3 shows that throughout the period, males with primary education accounted for about three quarters of all male activity, whereas only about $25 \%$ of females with primary education were in the labour market. Although the contribution of females in both the secondary and primary groups were quite small compared to males, the growth in females with tertiary education almost doubled during the sample period 1984-1997. Also, in the no schooling category, the percentages of females and males Din 1997 was half of that in 1984.

\section{Empirical Result}

Table 4 reports the parameter estimates of the earnings function for each sample year between 1984 and 1997. It should be noted that, in addition to the independent variables presented in Table 4, all regressions included sector indicators. The estimates of earning equations in Table 4 indicated the standard result that earnings have a quadratic relationship with age, though the results suggested that the age-earning profile became flatter over the 13-year period. The results presented here assumed the standard quadratic (in age) model first proposed by Mincer (1974). However, as Murphy and Welch (1992) pointed out, including higher order polynomials may actually provide a more robust estimating equation-their data suggest a quartic specification. We did experiment with some alternative (cubic and quartic) specifications but to little effect. More importantly, the focus here is on the rates of return to education 
(and not life cycle earnings patterns) and the quadratic specification is simply used as a control for life cycle effects.

The estimates presented in Equation 1 were estimated using ordinary least squares (OLS). This raised a number of estimation issues. Firstly, because the equation is estimated across employees only, there may be sample selection bias. Clearly, one solution would be to correct for potential bias using the standard Heckman correction model. However, this is not possible in the present context due to the fact that there are not sufficient instruments to allow estimation of the model and because Malaysian data on self-employment is very inaccurate due to the misreporting of self-employment status. Secondly, to identify the role of unobserved heterogeneity in the data, we used the Breasch-Pagan/ Cook-Weisberg tests. In fact, the regression results showed that the error terms are homoscedastic.

Equally, education is generally positively associated with earnings. The exception is that the return for other qualifications is lower than the return to no qualifications. However, generally, income increases monotonically with the level of qualification. Over the sample period, the return for a primary qualification decreased from 0.214 in 1984 to 0.164 in 1997. This result was consistent with the description of wage inequality, which, for the lowest $10 \%$, was worse in 1997. Interestingly, the return for a medium level qualifications, such as a secondary qualification, increased over the period, from 0.294 in 1984 to 0.394 in 1997. These results were consistent with the descriptive analysis in the previous section, which reported that the position of the medium level earner improved in 1997. They were also consistent with the finding that there has been an increase in the demand for labour at the semi-skilled level. As far as employees with secondary and high school qualifications are concerned, the results showed that the demand for this group is buoyant in the Malaysian labour market. It is important to note that this group of employees is classified as having medium level qualifications and generally belongs to the semi-skilled group. The favourable demand for semi-skilled workers over skilled workers has already been discussed.

At the higher levels of qualification, the return for having a degree fell, from 1.152 in 1984 to 0.931 in 1997; for diploma holders, the return decreased from 0.688 in 1984 to 0.631 in 1997. The trend between 1989 and 1995 , however, showed a general level of stability in the return to higher 
level qualifications. These results were consistent with the Malaysian Economic Report for 2002, which noted that the demand for workers in Malaysia generally favoured workers with medium level qualifications. Chung (2003) also reported that the private return for Malaysians in 1997 were positive, especially at secondary and higher levels of qualification. There are a number of factors that may explain the generally poorer situation found for 1997; one important factor is the influence of the 1997 recession. This recession resulted in major retrenchment in the labour market, with 50,000 workers losing their jobs in early 1997 and further losses of 100,000 workers by early 1999 (Malaysia, 2001).

Turning now to the returns associated with different occupations, these showed that managers have the highest return relative to production workers. In terms of trends, the results showed that the returns to all occupations decreased during the sample period relative to production workers, even while holding education constant. Managers, for example, (4) experienced the largest decrease in returns (around $38 \%$ ) during the sample period. During the period from 1984-1995, however, this occupation group showed an increasing trend, with return for managers undergoing a steady increase of $5.2 \%$. People in professional and clerical occupations experienced an upward turn during the 1984-1989 period, with peak return in 1989. The premia associated with these occupations fell in 1992 and continued to decrease until 1997. The return for workers -in sales occupations fluctuated during the 1984-1997 period; the premia Pfell in 1989 and increased in 1992, before dropping back in 1995 and 1997. Workers in the service occupations encountered the smallest fall, accounting for just $1 \%$ during the 1984-1997 period. This trend was Consistent throughout 1984-1989, before falling in 1992.

Ascanbeseenin Table4, wage premia relative to workingin manufacturing varied widely across sectors. The estimates in 1984, for example, ranged from 0.28 in the mining sector to -0.024 in the restaurant sector. Table 4 also suggests that employment in manufacturing is associated with higher wages when compared to those in the communications, wholesale, and restaurant sectors. In 1984, wages in the transportation sector were also lower compared with those in manufacturing, but the trend changed in 1989. The premium associated with working in this sector increased from 0.03 in 1989 to 0.075 in 1997. The highest wage premia were to be found in the mining sector, although they fell over the time period. In contrast, the wage advantage faced by employees in the electrical and finance sectors significantly increased over the period. 


\section{Table 4}

\section{Estimates of Earning Equations}

\begin{tabular}{|c|c|c|c|c|c|}
\hline & 1984 & 1989 & 1992 & 1995 & 1997 \\
\hline Constant & $6.105^{*}$ & $6.235^{*}$ & $6.629^{*}$ & $6.975^{*}$ & $7.361^{*}$ \\
\hline Age & $.110^{*}$ & $.107^{*}$ & $.095^{*}$ & $.087^{*}$ & $.077^{*}$ \\
\hline Age squared & $-.001^{*}$ & $-.001^{*}$ & $-.001^{*}$ & $-.001^{*}$ & $-.001^{*}$ \\
\hline Male & $.351^{*}$ & $.315^{*}$ & $.306^{*}$ & $.288^{*}$ & $.174^{*}$ \\
\hline Married & $.145^{*}$ & $.156^{*}$ & $.094^{*}$ & $.069^{*}$ & $.000^{*}$ \\
\hline Other Qualifications & $-.341^{*}$ & $-.3841^{*}$ & $-.0332^{*}$ & $-.297^{*}$ & $-.234^{*}$ \\
\hline Primary qualification & $.214^{*}$ & $.184^{*}$ & $.210^{*}$ & $.198^{*}$ & $.164^{*}$ \\
\hline Secondary qualification & $.294^{*}$ & $.337^{*}$ & $.366^{*}$ & $.368^{*}$ & $.394^{*}$ \\
\hline High school qualification & $.464^{*}$ & $.470^{*}$ & $.475^{*}$ & $.491^{*}$ & $.497^{*}$ \\
\hline Diploma & $.688^{*}$ & $.586^{*}$ & $.652^{*}$ & $.683^{*}$ & $.631^{*}$ \\
\hline Degree & $1.152^{*}$ & $1.092^{*}$ & $1.125^{*}$ & $1.126^{*}$ & $.931^{*}$ \\
\hline Professional & $.279^{*}$ & $.292^{*}$ & $.269^{*}$ & $.252^{*}$ & $.160^{*}$ \\
\hline Manager & $.803^{*}$ & $.819^{*}$ & $.835^{*}$ & $.855^{*}$ & $.419^{*}$ \\
\hline Clerical & $.200^{*}$ & $.206^{*}$ & $.166^{*}$ & $.126^{*}$ & $.120^{*}$ \\
\hline Sales & $.076^{*}$ & $.051^{*}$ & $.094^{*}$ & $.071^{*}$ & $.037^{*}$ \\
\hline Services & $.023^{* *}$ & $.023^{*}$ & $.001^{*}$ & $.010^{*}$ & $.013^{*}$ \\
\hline Mining & $.285^{*}$ & $.252^{*}$ & $.272^{*}$ & $.244^{*}$ & $.173^{*}$ \\
\hline Electrical & $.084^{*}$ & $.007^{*}$ & $.070^{*}$ & $.132^{*}$ & $.097^{*}$ \\
\hline Construction & $.006^{* *}$ & $-.095^{*}$ & $-.029^{*}$ & $.025^{*}$ & $.063^{*}$ \\
\hline Wholesale & $.005^{* *}$ & $-.046^{* *}$ & $-.062^{* *}$ & $-.051^{*}$ & $.012^{*}$ \\
\hline Restaurant & $-.024^{* *}$ & $-.052^{* *}$ & $-.059^{*}$ & $-.126^{*}$ & $-.025^{* *}$ \\
\hline Transportation & $-.011^{* *}$ & $.003^{* *}$ & $.031^{* *}$ & $.074^{*}$ & $.075^{*}$ \\
\hline Finance & $.064^{*}$ & $.047^{*}$ & $.091^{*}$ & $.155^{*}$ & $.100^{* *}$ \\
\hline Communication & $-.068^{*}$ & $-.060^{*}$ & $-.084^{*}$ & $-.106^{*}$ & $-.054^{*}$ \\
\hline Number of observations & 56191 & 57902 & 60978 & 44010 & 42196 \\
\hline$F$ test & 2035 & 2116 & 2742 & 2443 & 593 \\
\hline \multicolumn{6}{|l|}{$\begin{array}{l}\text { Breusch-Pagan / Cook- } \\
\text { Weisberg test for } \\
\text { constant } \\
\text { Variance }\end{array}$} \\
\hline Chi2 (1) & 16.14 & 18.09 & 13.95 & 20.15 & 27.14 \\
\hline Prob $>$ chi2 & 0.82 & 0.75 & 0.92 & 0.69 & 0.25 \\
\hline R squared & .474 & .521 & .480 & .462 & .247 \\
\hline
\end{tabular}

Note. ${ }^{*}$ significant at $5 \%$ level.

** significant at $10 \%$ levels. 


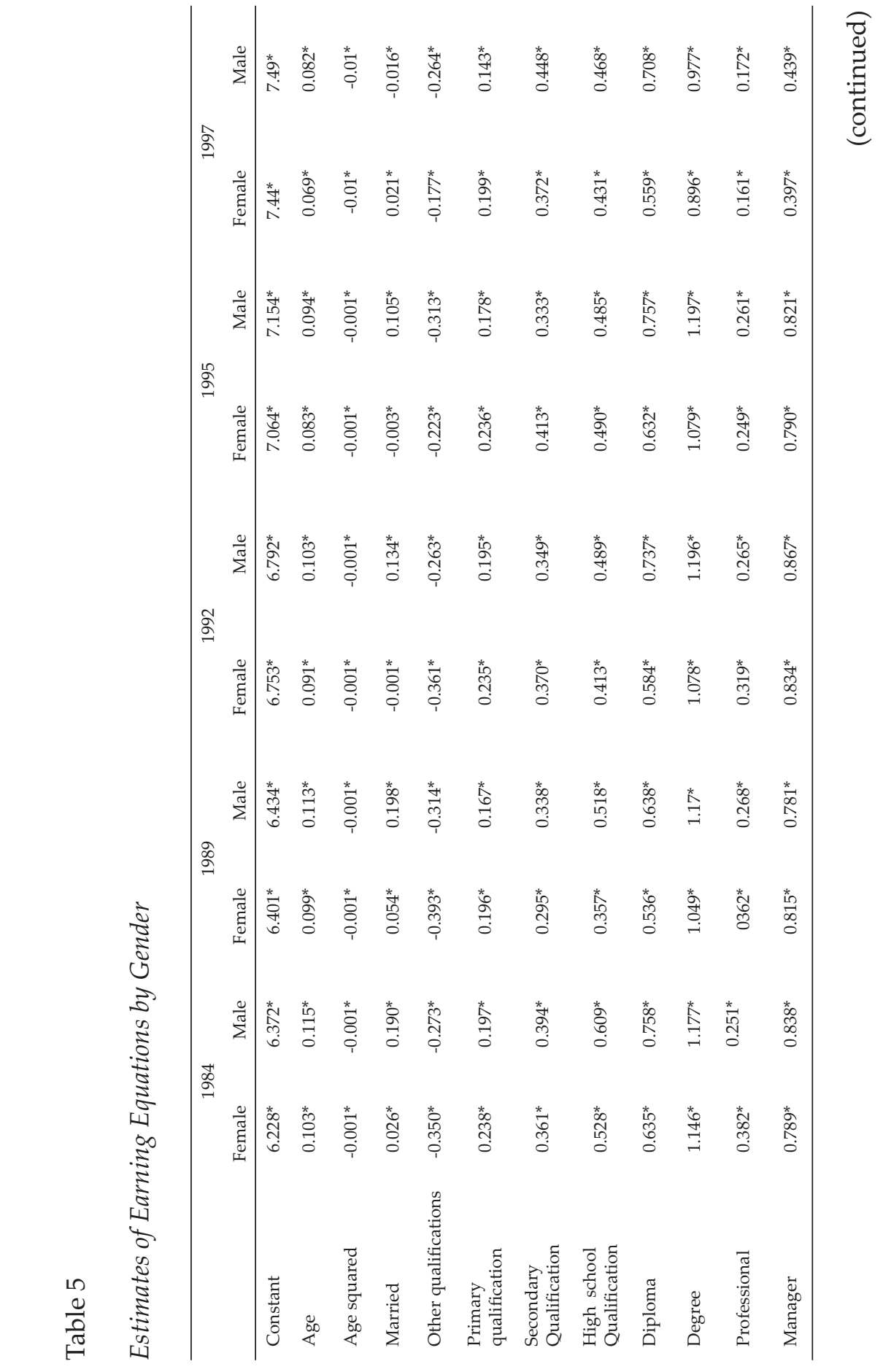

256 IJMS 16 (2), 243-262 (2009) 


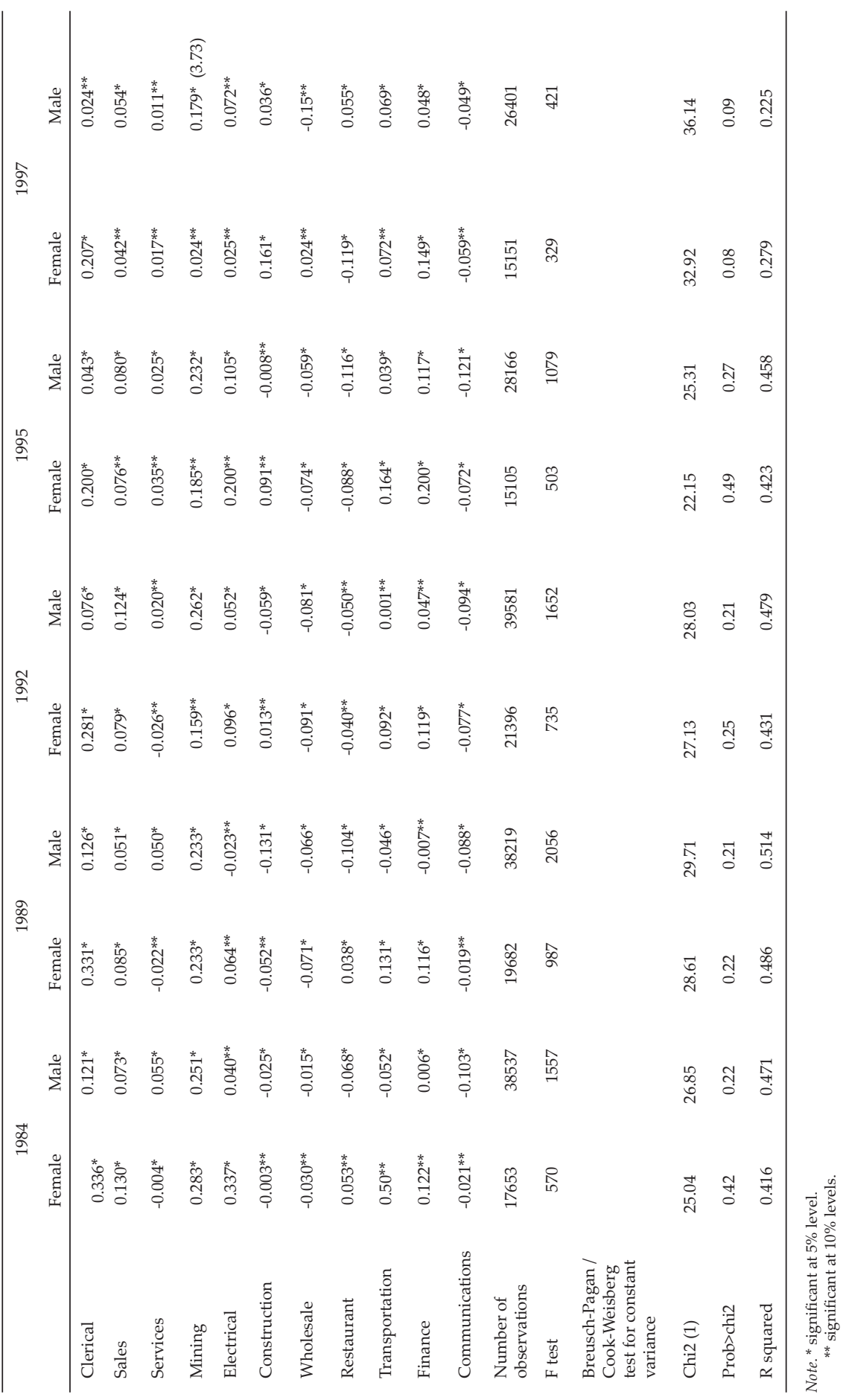


It is interesting to consider gender differentials in more detail. The results in Table 5 indicate a significant gender differential but also that this has fallen over time. In order to examine the impact of gender, we ran separate regressions for males and females. The results are presented in Table 5. In general, they indicated that the return to education for females at low levels of qualification is higher than the return obtained by males. However, at higher levels of qualifications, males traditionally have a higher return compared to female workers. On the whole, the results showed that the return for each level of qualification declined between 1984 and 1997, especially at the higher levels (diploma and degree). In 1984, the return for females with primary qualification was 0.23 , compared to a return for males of 0.19 . At primary qualification level, female returns decreased in 1989 and stabilised during the period between 1992 and 1995 at 0.23 , before decreasing in 1997 to 0.19 . The "return by males with primary qualifications showed a decreasing trend during the sample period. The return decreased from 0.19 in 1984 to 0.16 in 1989, before increasing to 0.19 in 1992. It then fell in 1995 and 1997 to 0.17 and 0.14 , respectively.

(1)

It was interesting to note that the return for males with a medium level of qualification (secondary and high school) was higher than that for females. The return to secondary qualifications for males seemed to have undergone a slight change; the range ran from $0.39 \%$ to $0.44 \%$ during the sample period. The return decreased from $0.39 \%$ in 1984 to $0.33 \%$ in 1989, and slightly increased to $0.34 \%$ in 1992 and 1995. The return by males with a secondary qualification, however, increased to $0.44 \%$ in 1997. The return by females with secondary qualifications decreased between 1984 and 1989 and increased between 1989 and 1995. In 1984, the return was $0.36 \%$, reducing to $0.29 \%$ in 1989 . However, the figure increased to $0.37 \%$ in 1992 and $0.41 \%$ in 1995, before dropping to 0.37 $\%$ again in 1997.

-

The impact of occupation affiliation is now considered. The coefficient estimates showed that females in certain occupations face higher premiums over production workers than males. The exception is for managerial and service occupations, which had a zero premium for men but a negative wage premium for women. However, in some groups, for example professional, technical, and related fields, the trend in premium favoured male workers with the returns increasing. In contrast, they have fallen for women. Looking at professional, technical, and related field occupations, during the period 1984 to 1992, the female return was higher than the male return, but this trend changed in 1995 and 1997. The return for females in 1995 was $0.24 \%$, compared to a male return of 0.26 $\%$. In 1997, the return for these occupation groups decreased for females and males to 0.16 and 0.17 , respectively. These results showed that the return for females in professional, technical, and related occupations 
was higher than the return faced by males during the 1980s and early 1990s. However, the trend changed in the mid-1990s, when the return for males became more than that for females.

Sector wage differences between males and females showed that the return for both was lower in the construction, wholesale, restaurant, and communications sectors relative to the manufacturing sector. During the first two periods, 1984 and 1989, the return for males in the transportation sector was also lower relative to the manufacturing sector. In some cases, for example in the electrical sector, females received a higher pay premium than men relative to their reference groups as they did in the mining sector. The return was equal in 1989 and during the 1990s, males were paid higher than females. The return for female workers continued to fall during the period 1992 to 1997.

\section{Policy Implication}

The Malaysian economy has been in a transitional stage for more than 50 years in an effort to develop the human capital. The National Education Policy was formulated in 1956 and revised in 1960 which aimed to formulate a standard curriculum structure in all schools in Malaysia, to have a smooth and well managed education system, and to provide education opportunities to children of lower income groups and those residing in rural areas.

During the Second Malaysia Plan, the education system aimed to promote national integration and close the gap in education opportunities among regions and races. Establishment of institutions, college and university, increased the levels of enrolment at the tertiary education level. Early 1980s, Malaysia witness an increment in enrolment of students at tertiary levels of education increasing from 11605 students in 1970 to 36809 students in 1980s. The Third Malaysia Plan was aimed to improve quality of education by providing schools with science laboratories. In 1979, the National Education Policy was reviewed and forwarded several recommendations to improve the education system. One of which was to acquire basic skills in reading, writing, and arithmetic. Although the development of IT started in 1985, when the Malaysian Government established the National Committee on Data Processing (NCDP) to promote IT environment in the Malaysian society, the achievement was not as great as anticipated. This was because the recession of 1985 had a major impact, and policy and expenditure decisions turned to solving standard of living and social economic problems. In 1987, the government started to introduce IT into the school syllabus to encourage 
knowledge attainment the Malaysian society. The implementation of this plan began in 1989, when the Ministry of Education formulated a "Computers in Education" programme. The Sixth Malaysia Plan (1991-1995) incorporated the first national IT programme and, in 1995, the Multimedia Super Corridor (MSC) was created and became the centrepiece of the national IT strategy in the Seventh Malaysia Plan (1996-2000). In the Eighth and Ninth Malaysia Plans, the highest priority was to change the domestic and economic landscape to one that was outward-looking and competitive at an international level. This was to be achieved by promoting the concept of globalisation, and extending the use of IT in education, government departments, and rural areas. The Plans also emphasised the development of human resources, focusing on education and training, in order to encourage research and -development (R\&D). Twinning programmes were offered by private colleges and universities aiming to provide better quality of education in Malaysia. The government also upgraded the level of college university to university level and fostered the growth of universities increasing from four government universities in 1970 to 22 government universities -by 2008.

The effects of the policy education of the Malaysia Plan, in 2007, Malaysia witnessed an increment by $36 \%$ of enrolment at tertiary levels of education; the number increased from 262, 626 students in 2002 to 358, 053 students in 2007 (Malaysia, 2008). The improvement of research and development also saw the transitions of new fields for example biotechnology, science geoinformation, biomolecule, and agrotechnology in the era of the Ninth Malaysia Plan. As a result, the return to education also is expected to have a positive return in 2007.

\section{CONCLUSION}

Typically, the return to higher levels of qualification (degree and diploma) is greater for males than for females over the period 1984-1997. On the other hand, the return to primary qualifications for females is higher than that for males. This lower return on education at higher levels for females is reflected in their lower enrolment in tertiary education. An historical perspective can explain this situation: women in Malaysia have distinct religious values and norms about many issues, especially concerning the commonly held belief that they are ideally suited to housework, clerical jobs, teaching, and similar "female gender" occupations, rather than as engineers and doctors. Furthermore, the 
large size of families in Malaysia, which averaged six children per family, is one of the factors influencing parents who choose their sons rather than their daughters to enter higher levels of education. With regard to occupational differentials, this was due to changes in the way the professional, technical, and related occupations category is defined. This category originally included teachers and nurses, where more than $70 \%$ were women (Malaysia, 1996). In 1991, for the first time a "Women in Development" chapter was included in the Sixth Malaysia Plan (19911995). Alongside this, the classification of the category was upgraded to include lecturers, doctors, lawyers, accountants, and engineers. As mentioned above, the stereotypical job for a female was a clerical job. Clerical occupation groups showed that the return for females was higher than that for males; however, the returns for both showed a constantly decreasing trend during the sample period.

\section{REFERENCES}

Acemoglu, \& Angrist. (2000). How large are human capital externalities? Evidence from compulsory schooling laws. MIT Department of Economics.

Arrazola, M., \& Hevia, J. (2008). Three measures of returns to education: An illustration for the case of Spain. Economics of Education Review, 27(issues 3), 266-275.

Becker, G. (1955). An economic analysis of discrimination. Chicago: University of Chicago Press.

Daron, A. (2003). Cross-country inequality trends. Economic Journal, 113,121-149.

International Monetary Fund (IMF), (1999). Malaysia: Recent economic development. Washington D.C.: International Monetary Fund.

Malaysia (1996). Seventh Malaysia plan 1996-2000. Kuala Lumpur: Government Press.

Malaysia (2001). Eighth Malaysia plan 2001-2005. Kuala Lumpur: Government Press.

Malaysia (2008). Kementerian Pengajian Tinggi. Kuala Lumpur: Goverment Press.

Miller, H. (1955). Role awareness as an objective of group work in teacher Education. Journal of Teacher Education, 6, 128-133.

Mincer, J. (1974). Schooling, experience, and earning. Columbia: Columbia University Press.

Murphy, K.M., \& Welch, F. (1992). The sturcture of wages. Quarterly Journal of Economics, 287-326. 
Self, S., \& Grabowski, R. (2004). Does education at all levels cause growth? India a case study. Economics of Education Review, 23, 47-55.

Schultz, T. (1959), Investment in man: An economist's view. Social Science Review, XXXIII/2, 109-17.

Taylor, K. (2002). The impact of technology and trade upon the returns to education and occupation. Applied Economics, 34, 1371-1377.

T. P Chung. (2003). Return to education: Updates for Malaysia. Applied Economics Letters, 10, 837-841.

Teixeira, P.N. (2007). Jacob mincer a founding father of modern labor economics. United States: Oxford University Press.

Tsou, M.K. (2002). Wage differentials in Taiwanese manufacturing, 19821997. Asian Economic Journal, 16, 318-33.

Wood, A. (1994). North-South trade, employment and inequality: Changing - fortunes in a skill-driven world. United States: Oxford University Press.

Zanchi, L. (1998). Interindustry wage differentials in dummy variable models.Economics Letters, 60, 297-301. 